\title{
A new species of the spider genus Notsodipus (Araneae: Lamponidae) from Western Australia
}

\author{
Norman I. Platnick and Nadine Dupérré \\ Division of Invertebrate Zoology, American Museum of Natural History, \\ Central Park West at $79^{\text {th }}$ Street, New York NY 10024 U.S.A.
}

\begin{abstract}
A new species of the ground spider family Lamponidae, Notsodipus limnati, is described from Western Australia.
\end{abstract}

\section{INTRODUCTION}

The 11 genera of centrotheline lamponids are known only from Australia (including Tasmania), New Guinea, and New Caledonia, and five of them (Bigenditia Platnick 2000, Prionosternum Dunn 1951, Asadipus Simon 1897, Notsodipus Platnick 2000, and Longepi Platnick 2000) are conspicuous members of the Western Australian ground spider fauna (Platnick 2000). Of these, Asadipus and Notsodipus are the most speciose, and in both cases over half their species occur in Western Australia. We describe here a new species of Notsodipus recently collected at Mount Gibson, and are pleased to participate in this celebration of the legacy of Carolus Linnaeus.

Our methods, and the format of the description, follow those used in the monograph of Platnick (2000).

\section{SYSTEMATICS}

Family Lamponidae Simon 1893

\section{Subfamily Centrothelinae Platnick 2000}

Notsodipus Platnick 2000

Notsodipus Platnick 2000: 269.

\section{Type species}

Notsodipus dalby Platnick 2000, by original designation.

\section{Remarks}

The genus Notsodipus occurs over much of mainland Australia, and is particularly abundant in the drier regions of the continent (Platnick 2000). There are currently 17 named species (Platnick 2000).

\section{Notsodipus linnaci new species}

$$
\text { Figures } 1 \mathrm{~A}-\mathrm{B}
$$

\section{Material examined}

Holotype

Australia: Western Australia: ¿, Mount Gibson iron-ore mine, Banded Ironstone Range, Iron Hill west facing, 29 $36^{\prime} 10^{\prime \prime} \mathrm{S}, 117^{\circ} 10^{\prime} 20^{\prime \prime} \mathrm{E}$ (GPS), 30 April-11 May 2005, M.S. Harvey, S. Thompson, wet pitfall trap (WAM T82881).

\section{Paratype}

Australia: Western Australia: 1 \&, Mount Gibson iron-ore mine, Ironstone Slope, Iron Hill east facing, $29^{\circ} 36^{\prime} 08^{\prime \prime} \mathrm{S}, 117^{\circ} 10^{\prime} 27^{\prime \prime} \mathrm{E}$ (GPS), 15-30 April 2005, S. Thompson, wet pitfall trap (WAM T82880).

\section{Diagnosis}

Because the ventral prong of the terminal apophysis terminates in a single sharp point, the tegulum has only a tiny proximal projection, the embolus extends only to the distal portion of the tegulum, the dorsal prong of the terminal apophysis does not form a tube-shaped structure behind the ventral prong and does not bear a prolaterally directed spur, and the retrolateral tibial apophysis is relatively short and has a relatively narrow base, males will key out to Notsodipus quobba Platnick, and may represent the sister species of $N$. quobbn, as these two species uniquely share a subdistal projection on the dorsal prong of the terminal apophysis. Males of $N$. limmari can be distinguished by having that projection directed prolaterally rather than distally, and by the larger tip of the dorsal prong of the terminal apophysis.

\section{Description}

\section{Male (based on holotype)}

Total length 3.1. Abdominal dorsum seemingly uniformly gray under scutum, venter unmarked. Leg spination: tibia III v0-0-1p. Retrolateral tibial apophysis relatively short, narrow at base; terminal apophysis with ventral prong terminating in single sharp point, dorsal prong wide, recurved, bearing subdistal, prolaterally directed projection (Figures 1A-B). 


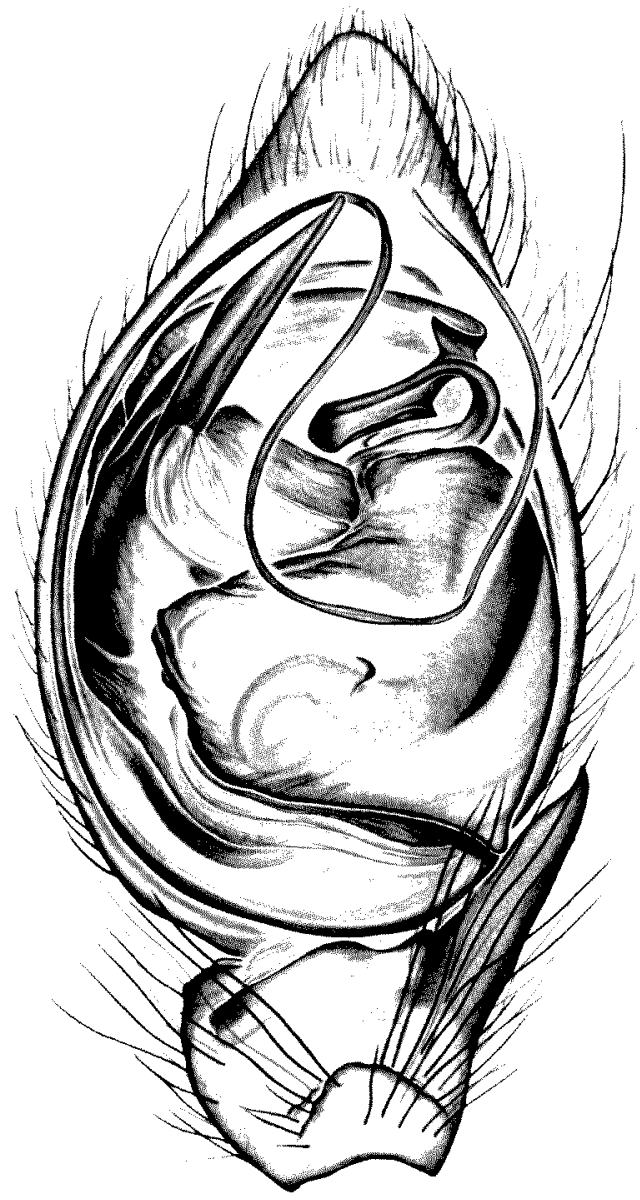

A

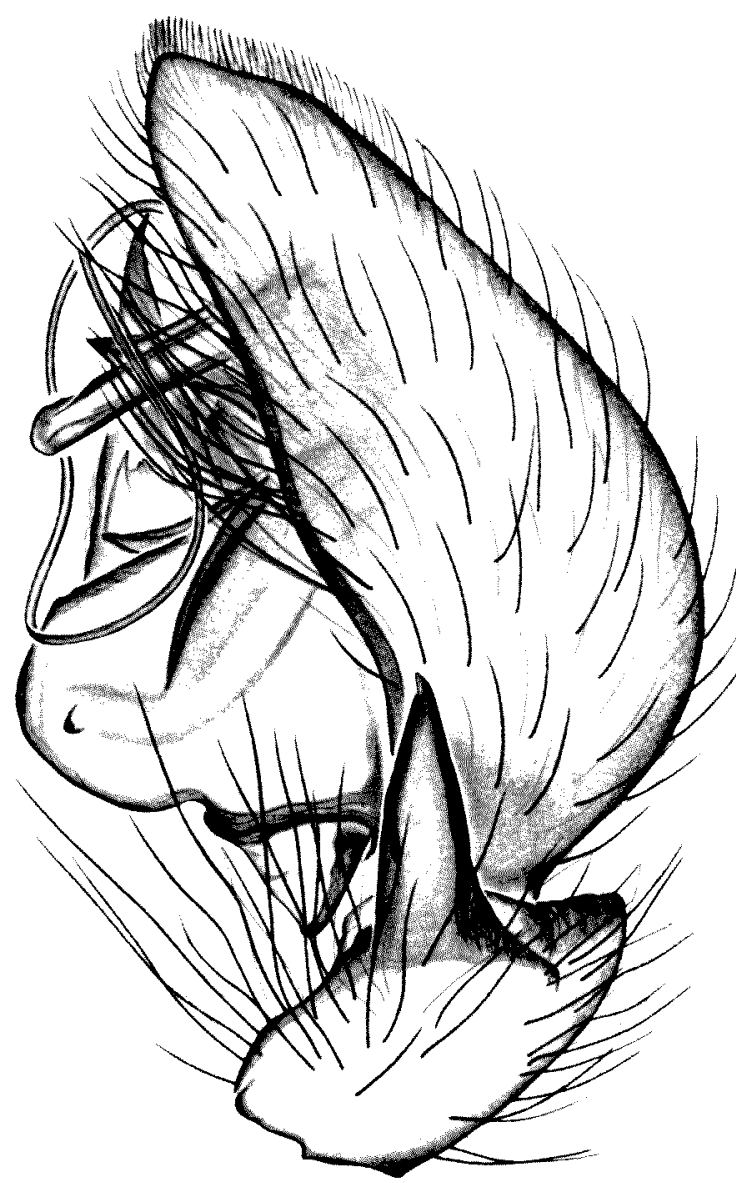

B

Figure 1 Notsodipus linnaci sp. nov, male holotype: A, left palp, ventral view; B, same, retrolateral view. Scale bar $=0.1$ $\mathrm{mm}$.

Female

Unknown.

Other material examined

None.

\section{Distribution}

Known only from Mount Gibson, Western Australia.

\section{Etymology}

The specific epithet in a patronym in honor of the founder of binomial nomenclature.

\section{ACKNOWLDGEMENTS}

We thank Mark Harvey and Julianne Waldock of the Western Australian Museum for the loan of the specimens.

\section{REFERENCE}

Platnick, N.I. (2000). A relimitation and revision of the Australasian ground spider family Lamponidae (Araneae: Gnaphosidae). Bulletin of the American Museum of Natural History 245: 1-330.

Manuscript received 28 February 2008; accepted 27 March 2008. 